\title{
Compatibility of tissue conditioners and denture cleansers: Influence on surface conditions
}

\author{
Hiroshi MURATA 1 , Hironori CHIMORI ${ }^{2}$, Guang HONG ${ }^{3}$, Taizo HAMADA ${ }^{3}$ and Hiroki NIKAWA ${ }^{4}$ \\ ${ }^{1}$ Department of Prosthetic Dentistry, Graduate School of Biomedical Sciences, Nagasaki University, 1-7-1 Sakamoto, Nagasaki 852-8588, Japan \\ ${ }^{2}$ Private practice, Hiroshima, Japan \\ ${ }^{3}$ Department of Oral Health Care Promotion, Graduate School of Dentistry, Tohoku University, 4-1 Seiryo-machi, Aoba-ku, Sendai 980-8575, Japan \\ ${ }^{4}$ Department of Oral Biology and Engineering, Graduate School of Biomedical Sciences, Hiroshima University, 1-2-3 Kasumi, Minami-ku, Hiroshima \\ 734-8553, Japan \\ Corresponding author, Hiroshi MURATA; E-mail: hmurata@nagasaki-u.ac.jp
}

\begin{abstract}
Chemical cleansing by denture cleansers is the first choice for denture plaque control of tissue conditioners. This study evaluated the influences of denture cleansers on the surface quality of tissue conditioners by determining surface roughness and porosity. Three tissue conditioners (Hydro-Cast, SR-Ivoseal, Visco-Gel) and 3 types of denture cleansers (Pika [enzyme type], Polident [neutral peroxide type with enzymes], Steradent [alkaline peroxide type]) were evaluated. Five specimens of each tissue conditioner/solution combination for each time period of immersion were prepared. The surface roughness of dental stone casts made from the tissue conditioners was evaluated using a profilometer. The surface quality of Hydro-Cast and Visco-Gel tended to be most deteriorated by the alkaline peroxide cleanser. The enzyme type of denture cleansers is most suitable for tissue conditioners in terms of surface quality. The suitable period for application of the enzyme cleansers would range from 3 to 7 days.
\end{abstract}

Keywords: Tissue conditioners, Denture cleansers, Surface conditions

\section{INTRODUCTION}

Denture plaque control using mechanical and chemical methods is essential for the maintenance of good oral hygiene of denture wearers ${ }^{1-3)}$. Mechanical methods are comprised of brushing with water and ultrasonic treatment, while chemical methods utilize immersion in denture cleansers ${ }^{2,4}$. The combination of both is more effective for the prevention of malodor, Candida albicans invasion, plaque and calculus formation, and denture-induced stomatitis as compared to each separately. Furthermore, the risk of infection, such as aspiration pneumonia in medicated elderly patients caused by ingestion of micro-organisms in denture plaque, is reduced by adequate denture plaque control $^{3)}$.

Soft denture liners are widely used for denture treatment in addition to hard denture base resins. Soft denture liners are divided into two main categories: (1) long-term soft denture liners and (2) tissue conditioners (short-term soft denture liners) $^{5)}$, while long-term soft liners can be further divided into silicone- and acrylic resin-based, according to their composition. These longterm materials are comprised of cross-linked amorphous polymers and used in patients who cannot tolerate a conventional hard denture base to cushion functional forces ${ }^{5)}$. Tissue conditioners are used as functional impression materials in addition to reconditioners for denture-bearing mucosa abused by illfitting dentures and temporary lining materials for immediate dentures and ill-fitting dentures ${ }^{6-10)}$. The materials are supplied as a separate powder and liquid. The powder generally consists of a polyethyl methacrylate or related copolymer material ${ }^{11}$, while the liquid is an ester plasticizer mixture, such as dibutyl phthalate, butyl phthalyl butyl glycolate, benzyl butyl phthalate, or dibutyl sebacate, with approximately 5 to 50 wt\% ethyl alcohol $(\mathrm{EtOH})^{12,13)}$. Since the powder component contains no initiator and the liquid no monomer, tissue conditioners are comprised of noncross-linked amorphous polymers ${ }^{5,11,12)}$.

It has been reported that soft denture liners can be deeply penetrated by Candida albicans ${ }^{14)}$, and that these materials promote greater levels of growth and/or colonization of Candida than hard denture base resins ${ }^{15-17)}$. Hard denture base resins can be cleaned by a combination of mechanical and chemical methods. However, soft materials, such as long-term soft denture liners and especially tissue conditioners, are damaged by brushing ${ }^{16,18)}$. Furthermore, ultrasonic treatment is not effective for removal of denture plaque ${ }^{16,19)}$. Thus, only chemical cleansing by denture cleansers can be applied to such soft materials ${ }^{16,18)}$. Alkaline peroxide cleansers, neutral peroxide cleansers with enzymes, and enzyme cleansers are presently available to denture wearers ${ }^{20)}$, though some types can cause deterioration of soft denture liners during immersion.

Previous studies investigated the influence of denture cleansers on the surface conditions and color stability of hard denture base resins ${ }^{21,22)}$ and long-term soft denture liners ${ }^{23)}$. In addition, the influence of such cleansers on the surface conditions of tissue conditioners has been evaluated by examining surface porosity ${ }^{16,18)}$. Surface quality, which is assessed by both surface roughness values and surface porosity, is one of the most important factors in regard to the efficacy of 
the components of functional impression materials ${ }^{24,25)}$. However, little information is available for the surface roughness values of dental stones casts made from tissue conditioners immersed in denture cleansers. The purpose of the present study was to evaluate the influence of denture cleansers on the surface quality of tissue conditioners and determine their compatibility. It was hypothesized that alkaline peroxide cleansers would produce a rougher surface condition and greater surface porosity of tissue conditioners than neutral peroxide cleansers with enzymes and enzyme cleansers.

\section{MATERIALS AND METHODS}

Tables 1 and 2 list the 3 tissue conditioners and 3 denture cleansers used in this study. The method used for measuring surface roughness values of the dental stone casts from the tissue conditioners has been previously reported ${ }^{24)}$. Immediately after mixing the powder and liquid of the tissue conditioner at $23 \pm 2^{\circ} \mathrm{C}$, according to the manufacturer's instructions, the mixture was poured into a polypropylene container with an inner diameter of $18 \mathrm{~mm}$ and depth of $2 \mathrm{~mm}$. A flat glass plate with a mean surface roughness value of $0.008 \mu \mathrm{m}$ was centered above the container and pressed down onto the mass of the tissue conditioner, then removed 2 hours after mixing. A total of 25 specimens were produced for each tissue conditioner/denture cleanser combination, which resulted in 5 specimens for each combination and time period of immersion. The test was conducted under conditions representative of a normal overnight cleansing regime. Five of each of the specimens were immersed into each of the 3 denture cleansers for 8 hours at $23 \pm 2^{\circ} \mathrm{C}$, washed with tap water and distilled water, then immersed in distilled water for 16 hours at $37^{\circ} \mathrm{C}$. Fresh denture cleanser solution was prepared each day. These processes were continually repeated for 14 days.

The surface roughness tests were conducted $0,1,3$, 7, and 14 days after specimen preparation. The containers containing the tissue conditioners were boxed with wax (Boxing Wax - X-Thin; Heraeus Kulzer, South Bend, Ind, USA) after immersion. A Type 4 dental stone (Die Stone, Heraeus Kulzer, South Bend, Ind, USA) and water were mixed at a water/powder ratio recommended by the manufacturer in a rubber bowl by hand, and then mechanically under a vacuum for 15 seconds. Each dental stone mixture was poured over the surface of each tissue conditioner specimen under gentle vibration, and stored in air at $23 \pm 2{ }^{\circ} \mathrm{C}$ for 60 minutes. The dental stone cast was then removed from the tissue conditioner and evaluated. Mean surface roughness $\left(R_{\mathrm{a}}\right)$ values were determined as the average of the centerline values using a profilometer

Table 1 Tissue conditioners tested

\begin{tabular}{|c|c|c|c|c|c|c|}
\hline \multirow{3}{*}{ Material } & \multirow{3}{*}{$\begin{array}{l}\text { Batch no. } \\
\text { powder-liquid }\end{array}$} & \multirow{3}{*}{ Manufacturer } & \multicolumn{3}{|c|}{ Composition } & \multirow{3}{*}{$\begin{array}{l}\text { Powder/liquid } \\
\text { ratio by weight }\end{array}$} \\
\hline & & & \multirow{2}{*}{ Powder ${ }^{11}$} & \multicolumn{2}{|l|}{ Liquid $^{12}$} & \\
\hline & & & & Plasticizer & EtOH (wt\%) & \\
\hline Hydro-Cast & $\begin{array}{l}1740110795- \\
1740110796\end{array}$ & $\begin{array}{l}\text { Kay-See Dental } \\
\text { Mfg Co, Kansas } \\
\text { City, Mo, USA }\end{array}$ & Polyethyl methacrylate & $\begin{array}{l}\text { Benzyl butyl } \\
\text { phthalate }\end{array}$ & 12.4 & 0.90 \\
\hline SR-Ivoseal & $\begin{array}{l}\text { B14124- } \\
\text { A25615 }\end{array}$ & $\begin{array}{l}\text { Ivoclar AG, } \\
\text { Schaan, } \\
\text { Liechtenstein }\end{array}$ & $\begin{array}{l}\text { Polyethyl methacrylate } \\
\text { Polymethyl methacrylate }\end{array}$ & Dibutyl sebacate & 48.1 & 1.50 \\
\hline Visco-Gel & $\begin{array}{l}0001000128- \\
0004000432\end{array}$ & $\begin{array}{l}\text { Dentsply DeTrey } \\
\text { GmbH, Konstanz, } \\
\text { Germany }\end{array}$ & $\begin{array}{l}\text { Polyethyl methacrylate } \\
\text { Polymethyl methacrylate }\end{array}$ & $\begin{array}{l}\text { Butyl phthalyl butyl } \\
\text { glycolate } \\
\text { Dibutyl phthalate }\end{array}$ & 4.9 & 1.21 \\
\hline
\end{tabular}

Table 2 Denture cleansers tested

\begin{tabular}{llllr}
\hline Material & Batch no. & Manufacturer & Type & $\begin{array}{c}\text { Peroxide content } \\
(\mathrm{mg} / \mathrm{tablet})^{20}\end{array}$ \\
\hline Pika & 918 & $\begin{array}{l}\text { Rohto Pharmaceutical Co, Ltd, } \\
\text { Osaka, Japan }\end{array}$ & Enzyme & 0 \\
Polident & F1108L4 & $\begin{array}{l}\text { GlaxoSmithKline KK, } \\
\text { Tokyo, Japan }\end{array}$ & $\begin{array}{l}\text { Neutral peroxide with } \\
\text { enzyme }\end{array}$ & 26.4 \\
Steradent & J118K & $\begin{array}{l}\text { Reckitt Benckiser Healthcare Ltd, } \\
\text { Hull, UK }\end{array}$ & Alkaline peroxide & 6.40 \\
& & & & 115.1 \\
\hline
\end{tabular}


(Surfcorder SE-3000; Kosaka Laboratory Ltd., Tokyo, Japan $)^{24)}$. The tracing had a length of $2.5 \mathrm{~mm}$ and a cut-off value of $0.8 \mathrm{~mm}$ was utilized. Three measurements for each specimen, namely, 15 measurements for each tissue conditioner/denture cleanser combination were made for each time period of immersion, and averaged. Distilled water was employed as a control solution.

The surface porosity of the tissue conditioners was examined according to methods previously described ${ }^{18,20)}$. Each sample was graded independently by three examiners with no knowledge of the test regime at the same time used in the surface roughness test. The ratings by the examiners were averaged to determine the severity of porosity and a score of 0 (none), 1 (slight), 2 (moderate), 3 (marked), or 4 (severe) was recorded. The surfaces were also examined using a laser microscope (VK-8510, Keyence Corp., Osaka, Japan) to evaluate the characteristics of three tissue conditioners.

The mean $R_{\mathrm{a}}$ value and standard deviation (SD) for the 5 specimens of each tissue conditioner/solution combination were calculated. Comparisons of $R_{\mathrm{a}}$ values were subjected to a 3-way analysis of variance (ANOVA), and the differences among the different types of tissue conditioners and among types of denture cleansers were also determined using a StudentNewman-Keuls test $(\alpha=0.05)$.

\section{RESULTS}

The 3-way ANOVA results indicated significant effects by the denture cleansers $(p<0.05)$ and time of immersion $(p<0.0005)$, as well as significant differences among the tissue conditioners $(p<0.0005)$ for the surface roughness $\left(R_{\mathrm{a}}\right)$ values of the dental stone casts made from the tissue conditioners (Table 3). Among all

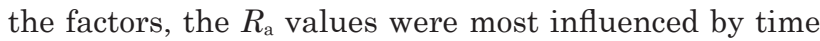
of immersion. Significant interaction between the tissue conditioners and time of immersion $(p<0.0005)$, and between the tissue conditioners and denture cleansers $(p<0.0005)$ also demonstrated that the $R_{\mathrm{a}}$ values from some of the tissue conditioners were affected more by the time of immersion and type of denture cleanser.

Variations among the $R_{\mathrm{a}}$ values of the dental stone casts made from the 3 tissue conditioners with time of

Table 3 Three-way ANOVA for the surface roughness $\left(R_{\mathrm{a}}\right)$ values of dental stone casts made from tissue conditioners

\begin{tabular}{|c|c|c|c|c|c|}
\hline Source & $\mathrm{df}$ & Sum of squares & Mean square & $\mathrm{F}$ & Significance of F \\
\hline Tissue conditioner & 2 & 73.009 & 36.504 & 77.074 & 0.000 \\
\hline Denture cleanser & 3 & 4.938 & 1.646 & 3.475 & 0.016 \\
\hline Time & 4 & 216.267 & 54.067 & 114.154 & 0.000 \\
\hline Tissue conditioner $\times$ Denture cleanser & 6 & 94.308 & 15.718 & 33.186 & 0.000 \\
\hline Tissue conditioner $\times$ Time & 8 & 283.490 & 35.436 & 74.818 & 0.000 \\
\hline Denture cleanser $\times$ Time & 12 & 59.611 & 4.968 & 10.488 & 0.000 \\
\hline Tissue conditioner $\times$ Denture cleanser $\times$ Time & 24 & 75.144 & 3.131 & 6.611 & 0.000 \\
\hline Residual & 840 & 397.849 & 0.474 & & \\
\hline Total & 899 & 1204.617 & & & \\
\hline
\end{tabular}

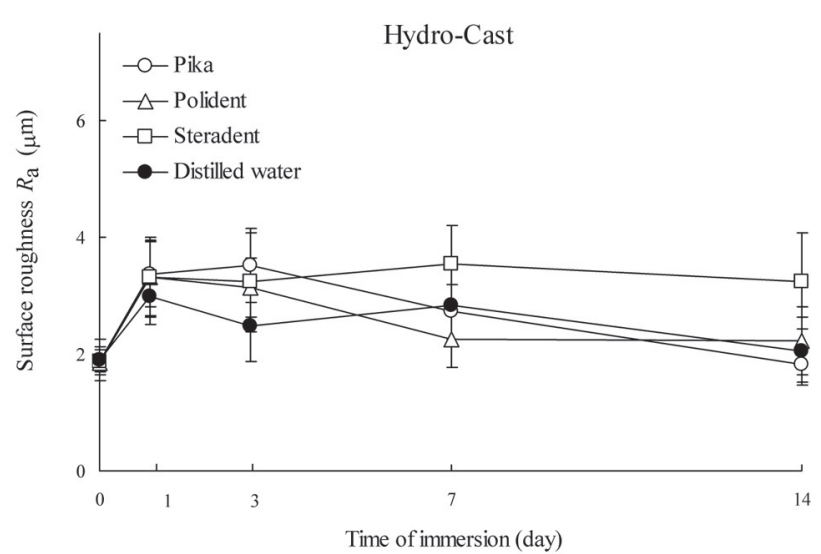

Fig. 1 Variations in surface roughness $\left(R_{\mathrm{a}}\right)$ values of dental stone casts made from Hydro-Cast with time of immersion in 3 different denture cleansers and water.

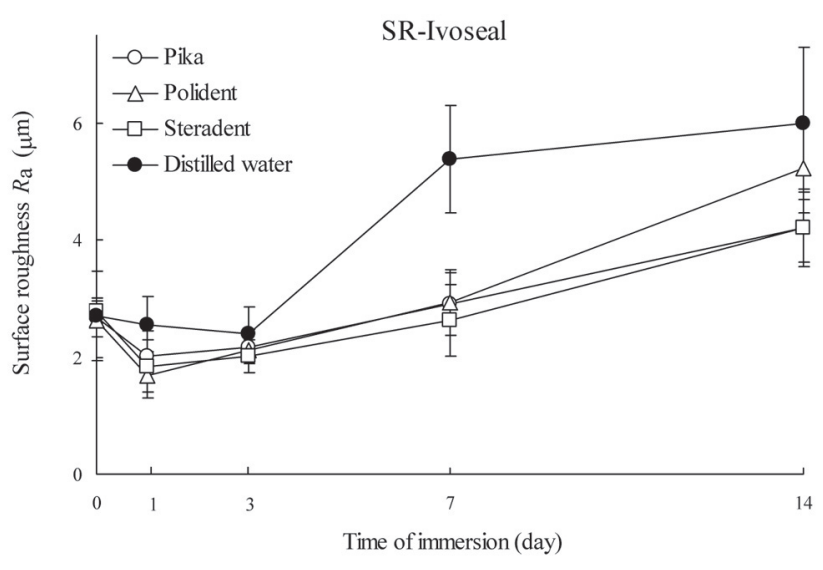

Fig. 2 Variations in surface roughness $\left(R_{\mathrm{a}}\right)$ values of dental stone casts made from SR-Ivoseal with time of immersion in 3 different denture cleansers and water. 


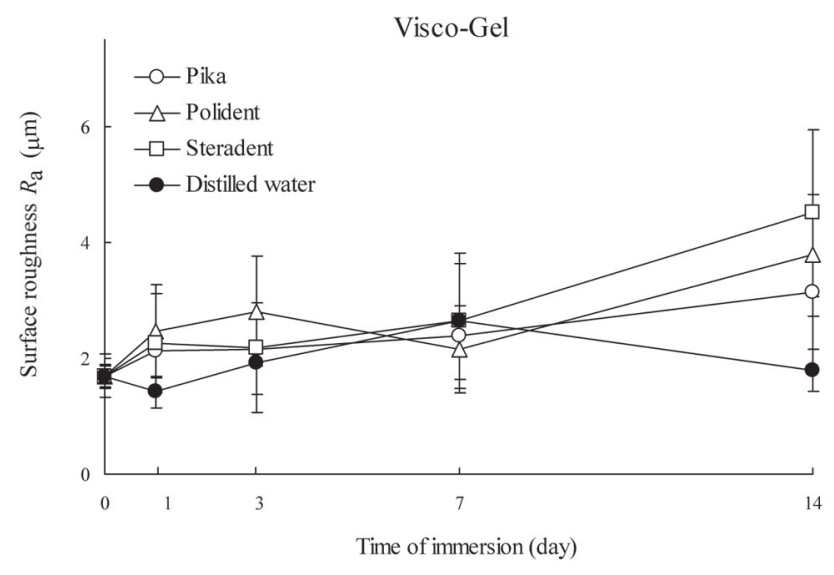

Fig. 3 Variations in surface roughness $\left(R_{\mathrm{a}}\right)$ values of dental stone casts made from Visco-Gel with time of immersion in 3 different denture cleansers and water.

immersion in the 3 denture cleansers and water are

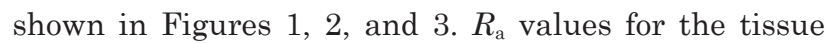
conditioners after being immersed in the solutions for 14 days are illustrated in Figure 4 . The mean $R_{\mathrm{a}}$ values of the dental stone casts made from Hydro-Cast and Visco-Gel not immersed in denture cleansers or water were significantly lower $(p<0.05)$ than those made from SR-Ivoseal. The $R_{\mathrm{a}}$ values of all tissue conditioner/ solution combinations tended to increase with the time of immersion of the tissue conditioners. However, large differences in the changes of surface roughness over time were found among the tissue conditioner/solution combinations, with SR-Ivoseal showing the greatest increase in $R_{\mathrm{a}}$ values as compared to Hydro-Cast and Visco-Gel when immersed in water.

The $R_{\mathrm{a}}$ values of the stone casts made from all of the Hydro-Cast/solution combinations increased until approximately 24 hours of immersion, after which those for Hydro-Cast in combination with Pika, Polident, and distilled water decreased gradually up to 14 days, while those for Hydro-Cast in combination with Steradent remained unchanged from 24 hours to 14 days. Stone casts made from Hydro-Cast immersed in Steradent for 14 days showed significantly higher $R_{\text {a }}$ values $(p<0.05)$ than when immersed in Pika, Polident, or distilled water. No significant differences were found among those latter 3 solutions.

The $R_{\mathrm{a}}$ values of the stone casts made from all of the SR-Ivoseal/solution combinations decreased until approximately 24 hours of immersion, and then dramatically increased from 3 to 14 days. Stone casts made from SR-Ivoseal immersed in distilled water for 14 days showed significantly higher $R_{\mathrm{a}}$ values $(p<0.05)$ than those immersed in any of the 3 denture cleansers.

The $R_{\text {a }}$ values of the stone casts made from all of the Visco-Gel/solution combinations showed a tendency to increase with time of immersion, with the greatest increases seen with Steradent. Stone casts made from
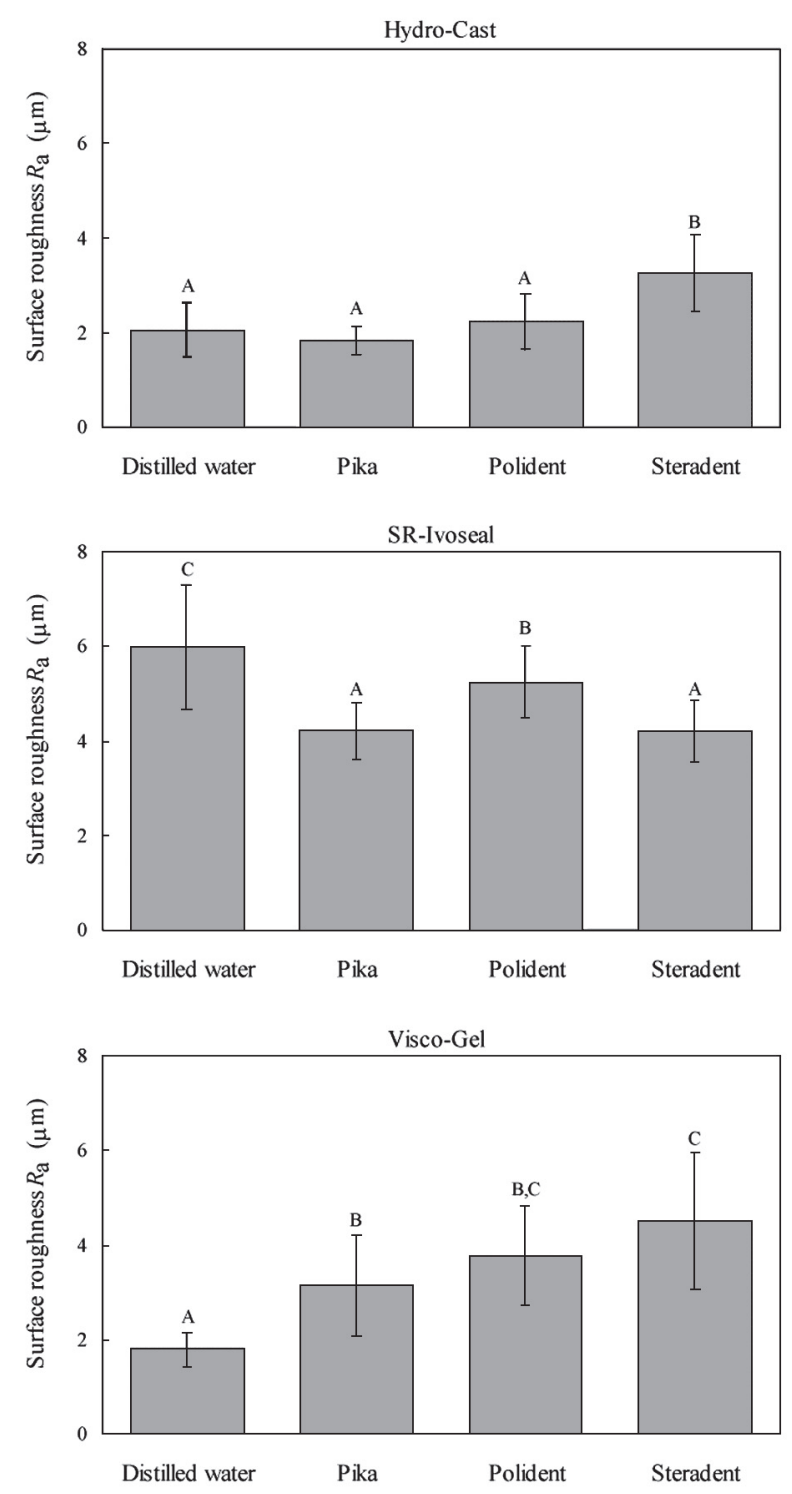

Fig. 4 Surface roughness $\left(R_{\mathrm{a}}\right)$ values of dental stone casts made from 3 different tissue conditioners after being immersed in 3 different denture cleansers and water for 14 days. Identical letters indicate no statistically significant difference.

Visco-Gel immersed in Steradent for 14 days showed higher $R_{\text {a }}$ values $(p<0.05)$ than those immersed in the other 2 denture cleansers or distilled water. The lowest value for surface roughness was seen with distilled water.

Figure 5 shows the results of surface porosity assessment of the tissue conditioners immersed in the denture cleansers. Representative photographs of the surface porosity are also shown in Figure 6. Large differences in the degree of surface porosity and influence of the denture cleansers were found among 
the tissue conditioner/denture cleanser combinations. SR-Ivoseal had less surface porosity than Hydro-Cast and Visco-Gel. Furthermore, the grade of surface porosity of SR-Ivoseal was scarcely influenced by any of the denture cleansers. Visco-Gel exhibited a more progressive change in surface porosity than the other 2 tissue conditioners with immersion in the denture cleansers. Steradent produced greater surface porosity with Hydro-Cast and especially Visco-Gel, as compared to Pika and Polident.

Figure 7 illustrates laser microscope images of surface condition of tissue conditioners. Rougher surface and lower surface porosity were observed in SR-Ivoseal, while smoother surface and greater surface

\begin{tabular}{|c|c|c|c|c|c|}
\hline & & 1 day & 3 days & 7 days & 14 days \\
\hline \multirow[t]{3}{*}{ Hydro-Cast } & Pika & & & & \\
\hline & Polident & & 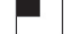 & & \\
\hline & Steradent & & & & \\
\hline \multirow[t]{3}{*}{ SR-Ivoseal } & Pika & & & & \\
\hline & Polident & & & & \\
\hline & Steradent & & & & \\
\hline \multirow[t]{3}{*}{ Visco-Gel } & Pika & & & & \\
\hline & Polident & & & & \\
\hline & Steradent & & & & \\
\hline none & slight & $\bmod$ & & rked & severe \\
\hline
\end{tabular}

Fig. 5 Grade of surface porosity of tissue conditioners immersed in 3 different denture cleansers for 1,3 , 7 , and 14 days. porosity were in Hydro-Cast and Visco-Gel.

\section{DISCUSSION}

The hypothesis that alkaline peroxide cleansers would deteriorate the surface quality of tissue conditioners was accepted except for one type of tissue conditioner that had a higher percentage of EtOH. Interestingly, that material was more influenced by distilled water than by the 3 denture cleansers. Furthermore, the influence of immersion time in the solutions on surface condition was found to be greater as compared to the type of denture cleanser.

In the present study, the surface conditions of tissue conditioners were evaluated by examining surface roughness and surface porosity. It is presumed that the Hydro-Cast and Visco-Gel would have lower surface roughness than SR-Ivoseal, whereas SR-Ivoseal would have a lower degree of surface porosity than those following immersion in distilled water as shown in Figure 7. The results of surface roughness were not consistent with those of surface porosity, thus it is necessary to measure both in order to obtain a clinically meaningful evaluation of the surface quality of tissue conditioners.

Hydro-Cast and especially Visco-Gel exhibited more progressive changes following exposure to the denture cleansers than to distilled water, as the surface roughness values and size of the bubbles increased with immersion time. The surfaces of Hydro-Cast and Visco-Gel tended to be more deteriorated by Steradent than by Polident, which in turn caused greater deterioration than Pika. Steradent is an alkaline peroxide cleanser that contains the largest amount of peroxide $^{20)}$ among the denture cleansers tested. It is considered that oxygenation in a strongly alkaline solution with Steradent would cause deterioration in the surface condition of a tissue conditioner. In
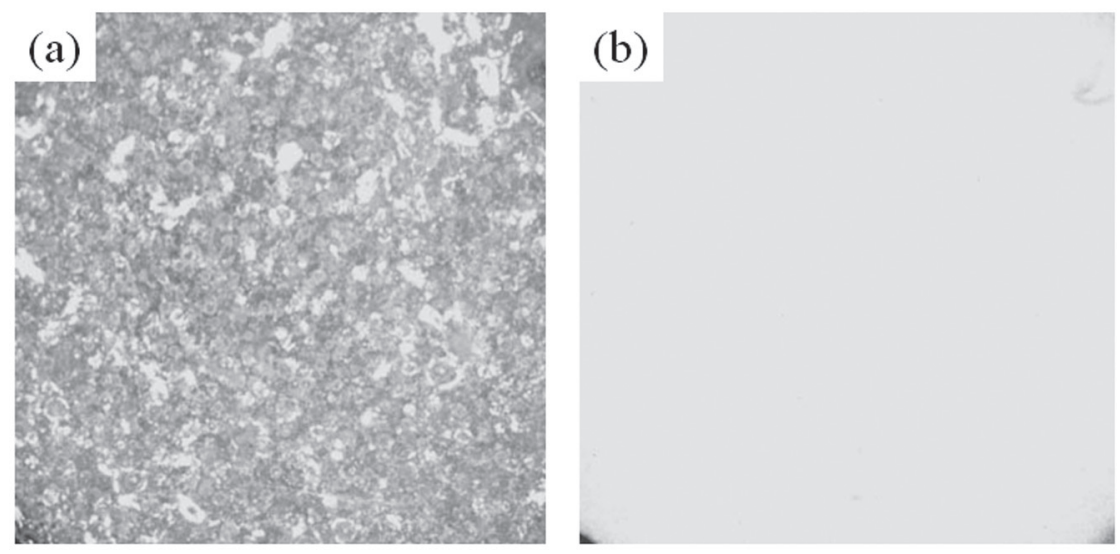

Hydro-Cast

\section{SR-Ivoseal}

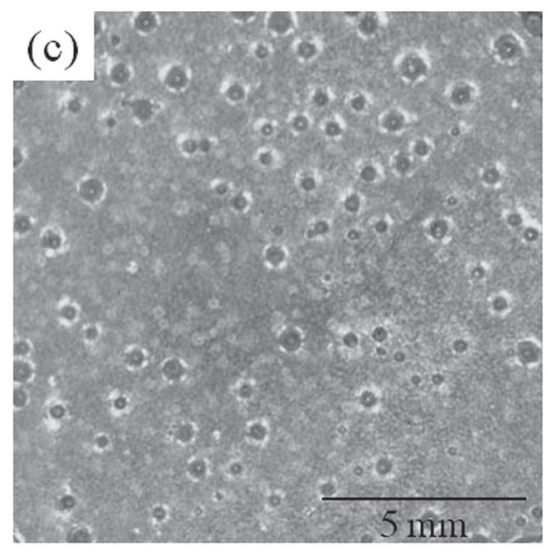

Visco-Gel

Fig. 6 Representative photographs of surface porosity of tissue conditioners. (a): moderate, (b): slight, (c): severe (Polident for 14 days). 

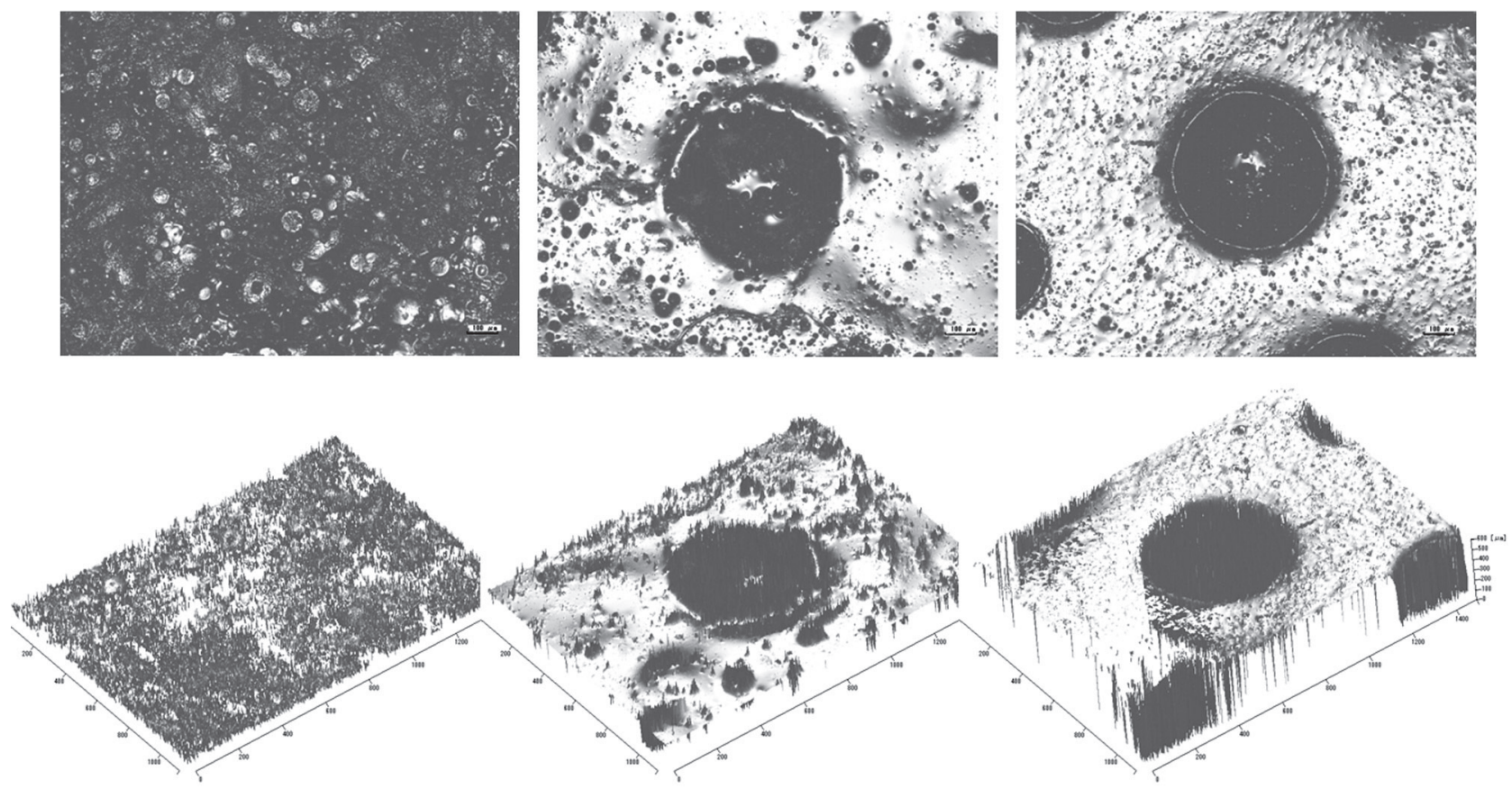

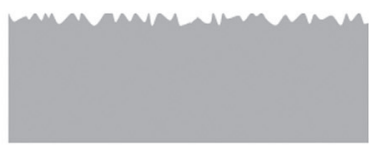

SR-Ivoseal

Hydro-Cast

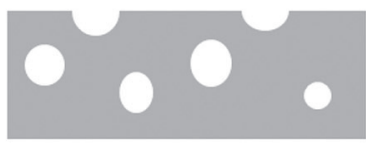

Fig. 7 Laser microscope images and schematic representation of surface condition of tissue conditioners.

contrast, Polident is a neutral peroxide cleanser with enzymes that contains a smaller amount of peroxide than Steradent. Therefore, the influence of Polident on the surface conditions was not greater than that of Steradent. Finally, Pika, an enzyme cleanser with no peroxide, had the least amount of influence on the surface condition of the 3 denture cleansers tested.

In contrast to Hydro-Cast and Visco-Gel, the surface of SR-Ivoseal was more deteriorated by distilled water than by the denture cleansers. SR-Ivoseal contains a considerably higher percentage of EtOH (48.1\%) in the liquid than Hydro-Cast $(12.4 \% \mathrm{EtOH})$ and Visco-Gel $(4.9 \% \text { EtOH })^{12,13)}$. Commercially available tissue conditioners generally contain approximately 5 to $20 \mathrm{wt} \% \mathrm{EtOH}^{12)}$. However, it has been reported that $\mathrm{EtOH}$ is lost within 24 hours after the material is immersed in water, whereas the loss of ester plasticizer ranges from 0.03 to $8.70 \mathrm{mg} / \mathrm{g}$ within 14 days $^{12)}$. Thus the loss of initial softness and surface integrity over time is caused by leaching out of the components contained in the liquids, especially $\mathrm{EtOH}$, and water absorption. The influence of the deterioration of SRIvoseal caused by leaching out of a larger amount of $\mathrm{EtOH}$ and water absorption is considered to be greater than the influence of the denture cleanser, thus the roughest surface condition with SR-Ivoseal was found following immersion in distilled water. This may be also attributed to differences in osmotic pressure or concentration against the material among the solutions.

Higher percentage of ETOH would lead to the rougher surface condition with time of immersion, while the smaller particle size of polymer powders and lower powder/liquid ratio would produce the smoother surface. On the other hand, the greater surface porosity will be associated with the higher viscosity just after mixing the powder and liquid. Therefore, differences in surface roughness and porosity were found among the tissue conditioners (Fig. 7).

Tissue conditioners can be used to treat abused mucosa, make functional impressions, and provisionally reline ill-fitting dentures and immediate dentures ${ }^{6-10}$. The materials are designed to flow under the continuous weak pressure caused by denture-bearing mucosa returning to their normal positions, and register the mean shape of the mucosa under functional stress, such as mastication, speech, swallowing, and parafunction $^{5,24}$. They should also have smooth surfaces 
during rest in the mouth, especially when used for functional impressions. The efficacy of the materials as functional impression materials is influenced by surface conditions, including roughness and porosity. The materials are left intraorally for at least 24 hours before pouring a dental stone cast, in order to make an accurate impression and avoid distortion of the impression surface caused by insufficient elastic recovery of the materials ${ }^{24}$. In the present study, the surface quality of the tested tissue conditioners was found to be more greatly influenced by the time of immersion in the solutions than by the type of denture cleanser, as shown by 3 -way ANOVA. The period of lining of the tissue conditioner in the mouth is important, as well as the compatibility of the tissue conditioner and denture cleanser. Although the ability of an enzyme-based cleanser to reduce colonized yeasts and/or fungal biofilm is lower than that of an alkaline peroxide cleanser and neutral peroxide cleanser with enzymes ${ }^{16)}$, the denture cleanser most suitable for tissue conditioners from the standpoint of surface condition is an enzyme type. The recommended period of application of an enzyme cleanser would be within 7 days for Hydro-Cast and SR-Ivoseal, and within 3 days for Visco-Gel. On the other hand, the alkaline peroxide type and neutral peroxide type with enzymes are not suitable for cleansing of a denture lined with a tissue conditioner, even though the microbiologic efficacy of those denture cleansers is higher. It is conceivable that oxygenation produced by peroxide and the alkaline condition caused deterioration of the surface conditions of the tested tissue conditioners.

It should be noted that the above suggestions are based on results obtained from the present study. There are many factors involved with the surface conditions of tissue conditioners, such as the influences of saliva, masticatory force, and thermal cycling, in addition to those of denture cleansers. A study of their influence is needed. Several types of dental stone are used in clinical situations. It has been reported that the surface roughness value of Die Stone made from a vinyl polysiloxane impression material (Examixfineinjection type) is $0.79 \pm 0.05 \mu^{24)}$, which would represent the surface condition of the dental stone itself. This previous study also has demonstrated that there is no relationship between type of dental stone and compatibility with tissue conditioners ${ }^{24)}$. Thus, Die Stone, which is Type 4, was used in the present study. Some differences in surface roughness values of the dental stone cast made from Visco-Gel were observed between the present and previous studies ${ }^{24)}$. The experimental conditions such as velocity of removal of tissue conditioners from the glass plate and volatility of ethyl alcohol in the liquid of the material during specimen preparation, which lead to the change of adhesion strength, are considered to influence the surface roughness. The same experimenter prepared the specimens to unify the experimental conditions in the present study.

An ideal denture cleanser should have a high ability to reduce fungal biofilm viability and not cause deterioration of dental materials such as tissue conditioners, long-term soft denture liners, and acrylic denture base materials. On the other hand, an ideal tissue conditioner would have a smoother surface and less surface porosity, while it should also be resistant to a denture cleanser with high cleansing efficacy. A previous study reported development of a tissue conditioner with the antimicrobial material Agzeolite $^{17)}$. However, such tissue conditioners and denture cleansers have not been tested in clinical situations. Further research for the development and clinical application of such materials is necessary in order to establish effective denture plaque control in patients wearing dentures lined with the tissue conditioners. At the present time it is important for dentists to understand the compatibility of tissue conditioners and denture cleansers, and provide correct information regarding suitable denture cleansers and their usage to their patients wearing a denture lined with a tissue conditioner. Although the microbiologic efficacy of enzyme denture cleansers is lower than that of alkaline peroxide denture cleansers and neutral peroxide denture cleansers with enzymes, the dentists should instruct the patients to use the enzyme type.

\section{CONCLUSION}

Within the limitations of this study, the following conclusions were drawn:

1. Measurements of both surface roughness values and degree of surface porosity are necessary to evaluate the surface quality of tissue conditioners.

2. The type of denture cleanser and tissue conditioner, and especially time of immersion in solutions had a significant influence on the surface quality of the tested tissue conditioners $(p<0.05, p<0.0005$ and $p<0.0005$, respectively).

3. From the standpoint of surface quality, enzyme cleansers are suitable for cleansing a denture lined with a tissue conditioner. The period recommended for application of the enzyme cleanser would range from 3 to 7 days, depending upon the type of tissue conditioner utilized. Alkaline peroxide cleansers and neutral peroxide cleansers with enzymes are not recommended for chemical cleansing of tissue conditioners.

\section{ACKNOWLEDGMENTS}

This research was supported in part by a grant-in-aid (no. 20390491) for Scientific Research from the Ministry of Education, Culture, Sports, Science and Technology, Japan.

\section{REFERENCES}

1) Jagger DC, Harrison A. Denture cleansing -the best approach. Br Dent J 1995; 178: 413-417. 
2) McCabe JF, Murray ID, Kelly PJ. The efficacy of denture cleansers. Eur J Prosthodont Restor Dent 1995; 3: 203-207.

3) Nikawa H, Hamada T, Yamamoto T. Denture plaque — past and recent concerns. J Dent 1998; 26: 299-304.

4) Paranhos HFO, Silva-Lovato CH, Souza RF, Cruz PC, Freitas KM, Peracini A. Effects of mechanical and chemical methods on denture biofilm accumulation. J Oral Rehabil 2007; 34: 606-612.

5) Murata H, Taguchi N, Hamada T, Kawamura M, McCabe JF. Dynamic viscoelasticity of soft liners and masticatory function. J Dent Res 2002; 81: 123-128.

6) McCarthy JA, Moser JB. Tissue conditioners as functional impression materials. J Oral Rehabil 1978; 5: 357-364.

7) Harrison A. Temporary soft lining materials. A review of their uses. Br Dent J 1981; 151: 419-422.

8) Qudah S, Harrison A, Huggett R. Soft lining materials in prosthetic dentistry: a review. Int J Prosthodont 1990; 3: 477-483.

9) Murata H, Narasaki Y, Hamada T, McCabe JF. An alcoholfree tissue conditioner - a laboratory evaluation. J Dent 2006; 34: 307-315.

10) Chander S, Hill M, Moore D, Morrow L. Tissue conditioning materials as functional impression materials. Eur J Prosthodont Restor Dent 2007; 15: 67-71.

11) Jones DW, Hall GC, Sutow EJ, Langman MF, Robertson KN. Chemical and molecular weight analyses of prosthodontic soft polymers. J Dent Res 1991; 70: 874-879.

12) Jones DW, Sutow EJ, Hall GC, Tobin WM, Graham BS. Dental soft polymers: plasticizer composition and leachability. Dent Mater 1988; 4: 1-7.

13) Wilson J. In vitro loss of alcohol from tissue conditioners. Int J Prosthodont 1992; 5: 17-21.

14) Allison RT, Douglas WH. Micro-colonization of the denturefitting surface by Candida albicans. J Dent 1973; 1: 198201.

15) Graham BS, Jones DW, Burke J, Thompson JP. In vivo fungal presence and growth on two resilient denture liners. J Prosthet Dent 1991; 65: 528-532.
16) Nikawa H, Yamamoto T, Hamada T, Rahardjo MB, Murata $\mathrm{H}$. Commercial denture cleansers -cleansing efficacy against Candida albicans biofilm and compatibility with soft denture-lining materials. Int J Prosthodont 1995; 8: 434444.

17) Nikawa H, Yamamoto T, Hamada T, Rahardjo MB, Murata H, Nakanoda S. Antifungal effect of zeolite-incorporated tissue conditioner against Candida albicans growth and/or acid production. J Oral Rehabil 1997; 24: 350-357.

18) Harrison A, Basker RM, Smith IS. The compatibility of temporary soft materials with immersion denture cleansers. Int J Prosthodont 1989; 2: 254-258.

19) Budtz-Jørgensen E. Materials and methods for cleaning dentures. J Prosthet Dent 1979; 42: 619-623.

20) Nikawa $H$, Iwanaga $H$, Hamada $T$, Yuhta S. Effects of denture cleansers on direct soft denture lining materials. $J$ Prosthet Dent 1994; 72: 657-662.

21) Harrison Z, Johnson A, Douglas CWI. An in vitro study into the effect of a limited range of denture cleaners on surface roughness and removal of Candida albicans from conventional heat-cured acrylic resin denture base material. J Oral Rehabil 2004; 31: 460-467.

22) Hong G, Murata H, Li YA, Sadamori S, Hamada T. Influence of denture cleansers on the color stability of three types of denture base acrylic resin. J Prosthet Dent 2009; 101: 205-213.

23) Jin C, Nikawa H, Makihira S, Hamada T, Furukawa M, Murata $\mathrm{H}$. Changes in surface roughness and colour stability of soft denture lining materials caused by denture cleansers. J Oral Rehabil 2003; 30: 125-130.

24) Murata H, Hong G, Li YA, Hamada T. Compatibility of tissue conditioners and dental stones: effect on surface roughness. J Prosthet Dent 2005; 93: 274-281.

25) Hong G, Li YA, Maeda T, Mizumachi W, Sadamori S, Hamada T, Murata H. Influence of storage methods on the surface roughness of tissue conditioners. Dent Mater J 2008; 27: 153-158. 